\title{
AN APPLICATION OF THE CONCEPT OF THE THERAPEUTIC ALLIANCE TO SADOMASOCHISTIC PATHOLOGY
}

This paper traces the history of the therapeutic alliance concept, examining how it has been used and misused, at times elevated to a central position and at others rejected altogether. The loss of this concept created a vacuum in classical psychoanalysis that has been filled by rival theories. The continuing usefulness of looking at the treatment process through the lens of the therapeutic alliance, particularly in relation to the manifold difficulties of working with sadomasochistic pathology, is suggested. To this end, revisions of the theory of the therapeutic alliance are suggested to address some of the difficulties that have arisen in conceptualizing this aspect of the therapeutic relationship, and to provide an integrated dynamic model for working with patients at each phase of treatment. This revised model acknowledges the complexity of the domain and encompasses the multiple tasks, functions, partners, and treatment phases involved. The utility of the revised theory is illustrated in application to understanding the sadomasochistic, omnipotent resistances of a female patient through the phases of her analysis.

$A$ 11 clinicians, regardless of theoretical orientation or level of experience, face the problems of helping patients enter treatment, stay and work effectively, leave in a timely fashion, and retain the gains after therapy is over. These problems are addressed with many different tools from psychoanalytic theory and clinical technique, among which has

Kerry Kelly Novick is on the faculty of the Michigan Psychoanalytic Institute and is Clinical Director of Allen Creek Preschool. Jack Novick is a Training and Supervising Analyst of the New York Freudian Society, a Child and Adolescent Supervising Analyst at the Michigan Psychoanalytic Institute, and Clinical Associate Professor in the Medical Schools at the University of Michigan and Wayne State University.

Submitted for publication September 16, 1996. 
been the concept of the therapeutic alliance. Sadomasochistic pathology has always been recognized as a major source of resistance to therapeutic progress. We have found, as have others from Freud on (1909, 1940; Meyers 1988), that sadomasochism makes analyses long and arduous because of the self-destructive character of the pathology, its roots at every level of development and the intense countertransference reactions evoked. In our work with severely disturbed children, adolescents, and adults, and in our infant and toddler observations, we have repeatedly discerned patterns of sadomasochism with the beating fantasy as its essence, the delusion of omnipotence as the core of the fantasy, and externalization as a major mechanism in the development and functioning of this pathology (K. Novick and J. Novick 1987; J. Novick and K. Novick 1991, 1996b).

Our work has led us to the view that omnipotence is not part of normal development but instead represents a hostile defensive reaction to failures of reality. This implies a separate pathway of pathological development in contrast to a normal system of self-esteem regulation based on an economy of pleasure from competence at each phase of development (J. Novick and K. Novick 1996a). When we describe two systems, the competent one open to inner and outer realities, the omnipotent one closed within a self-perpetuating, sadomasochistic fantasy, we are not referring to distinct psychic structures, such as id, ego, superego, or particular developmental stages, or distinct topographic dimensions of the conscious and unconscious regions of the mind, each with a different type of thought organization. Rather, we are referring to two modes of conflict resolution and self-esteem regulation, each of which is a possible response to conflict at any point in development. In our earlier studies we described how each phase of development contributes a strand to the formation of an open or closed system of conflict resolution and self-regulation, which in turn affects development in each subsequent phase and operates through deferred action to revise the memory and meaning of earlier phases (J. Novick and K. Novick 1996a; J. Novick 1999).

Our view is that sadomasochism and its omnipotent core fantasies are not aspects of normal development but represent pathological solutions to conflict. This is currently a minority position (cf. Shengold 1995), but we think conceptualizing sadomasochism as a line of pathological development has important implications for the goals of treatment and the nature of therapeutic action. Rather than demanding 
that patients give up and then mourn the loss of so-called "normal omnipotence," we understand the goal of treatment to be discovering and elucidating alternatives to omnipotent functioning and sadomasochistic relationships. This will not take away conflicts, which are universal and inevitable, but can restore to the patient the possibility of choice of conflict resolutions.

How are clinicians then to deal with sadomasochism and its omnipotent fantasy core? Are we still as helpless as Freud felt in 1909, and again in 1940, when he described these as the most difficult and intractable clinical situations, a feeling echoed in 1988 by Helen Meyers? We think it is partly in response to the feeling of helplessness in the face of such powerful resistances that analysts have sometimes reached for rival partial theories and radical techniques, currently manifested in the vogue for object relations, intersubjective, and self psychologies derived from the British object relations school. In a series of papers (J. Novick 1970, 1991, 1992; K. Novick 1991; K. Novick and J. Novick 1994a,b, 1996) we have suggested that a developmentally informed revised concept of the therapeutic alliance can address these issues within a classical framework of theory and technique.

Different ways of thinking about the therapeutic alliance and changes in assessment of its importance may be traced in the history of psychotherapeutic technique. If we look at the history of this concept, we may see how it has been used and misused, at times elevated to a central position and at others rejected altogether. In this paper we will present our understanding of the usefulness of looking at the treatment process through the lens of the therapeutic alliance, particularly in relation to the manifold difficulties of working with sadomasochistic pathology. We will outline our revised theory of the therapeutic alliance in order to address some of the difficulties that have arisen in conceptualizing this aspect of the therapeutic relationship, and to provide an integrated dynamic model for working with patients at each phase of treatment. In order to make sense of our suggested revisions to the theory and technique of working with the therapeutic alliance, we must look briefly at the evolution of psychoanalytic ideas about the nature of the therapeutic relationship, the early history of the concept that became the "therapeutic alliance."

We can begin with Freud's "The Dynamics of Transference" (1912) and "On Beginning the Treatment" (1913). There he develops the idea of the friendly, affectionate part of the transference and advises the 
analyst not to interpret until a proper rapport has been established. To do this, he counsels, the analyst should not "take up any standpoint other than one of sympathetic understanding" (1913, p. 140; emphasis added). Pigman (1995) and Shaughnessy (1995) have questioned Strachey's translation of the German Einfühlung as "sympathetic understanding," a term that connotes a passive listening stance rather than empathic listening, which for Freud was an active intellectual process of putting oneself in the place of the other. As Pigman (1995) demonstrates, empathy for Freud was "everything an analyst should do in a positive sense" (p. 252), the analyst's active contribution to the rapport that is the prerequisite for interpretation. Shaughnessy explicitly links Freud's use of the term empathy with a modern concept of the therapist's role in the working alliance, as does Meissner (1996).

It appears then that Freud's early concepts of rapport, of affectionate, unobjectionable transference by the patient, and of empathy by the analyst were all intended to be taken as elements of a collaboration, a relationship that is the condition and context for the work of interpretation. This view appears throughout Freud's writings and continues to the very end, in his 1940 idea of the "analytic pact" (p. 173). Sterba (1934) was the first to speak explicitly of an "alliance" when he described the analyst working together with that part of the patient's ego that is consonant with reality. Sterba built on Freud's description of collaboration with the patient to include an emphasis, then new, on ego psychology. Implicit in his paper is the distinction between the motivation for forming an alliance and the ego functions involved. Sterba's formulation became the standard and persisted as the usual meaning ascribed to "alliance." Bibring (1937) wrote of "an alliance with the ego" (p. 185), assisted by the patient's wish to be cured that resides in the synthetic function of the ego. Zetzel (1956) harked back to Freud to differentiate "transference as therapeutic alliance and the transference neurosis ..." (p. 370). She described the former as based on mature ego functions and in a later paper (1965) elaborated her description of the alliance as a repetition of the early mother-child relationship.

The concept of the alliance reached a peak in the work of Greenson (1965b, 1970, 1971). He viewed what he called the working alliance as based on the real relationship between patient and analyst that was best fostered by the analyst's humanness. We can conclude that the alliance between patient and analyst has been seen in terms of issues of relationship from its beginnings in Freud's formulations through to the work 
of Greenson and those who espoused his description. It has always assumed, in Balint's terminology (1968), a two-person psychology.

The importance of a therapeutic alliance for the successful pursuit of an analysis was a notion that was generally stressed in technical discussions during the 1960s and 1970s. Therapeutic alliance was a concept that allowed for new ways to look at psychoanalytic technique, particularly the analytic setting, transference and nontransference elements in the therapeutic relationship, and issues in termination. It also highlighted the differences between Kleinian and classical analysis. There was widespread agreement with Greenson that the working alliance should be distinguished from transference, that it was equally important for analytic work, and that it was based on the conscious and rational wish to be rid of suffering. Greenson's formulations crystallized the definition and attributes of the alliance. Both opponents and proponents ever since refer any controversy to a concept formulated in his terms.

Early on, the child analytic literature questioned the Greensonian description of the alliance (A. Freud 1962, 1965, cited in Sandler, Kennedy, and Tyson 1980; Frankl and Hellman 1962; Hamm 1967; Harley 1967; J. Novick 1970, 1980), but the concept of the therapeutic alliance as a rational, nontransferential motive for change persisted in the adult literature until 1979, when critical articles by Brenner, Curtis, and Kanzer seemingly succeeded in rendering the term obsolete. Brenner, for example, argued that the working alliance cannot be distinguished from transference and so is of no value. He said that the distinction between alliance and transference "is a specious one and its consequences for analytic practice are, generally speaking, undesirable" (1979 p. 155). This view was echoed a few years later by Weinshel (1984), who said that the concept of a working alliance can be a potentially harmful or confusing guide. The almost total dismissal of a formerly central technical idea is reflected in the current official psychoanalytic glossary of terms and concepts, where the working alliance is described as "both ambiguous and controversial" (Moore and Fine 1990, p. 195). Tellingly, in a 1990 issue of Psychoanalytic Quarterly devoted to psychoanalytic process, not a single reference was made to the concept of therapeutic or working alliance.

It is ironic that, just when many psychoanalysts have dismissed the concept of therapeutic alliance as ambiguous, unnecessary, or even harmful, research in the adjoining fields of psychiatry, counseling, and 
psychotherapy finds that the quality of the working alliance is a critical factor in predicting outcome (Frieswyck et al. 1986; Gelso and Carter 1985; Horvath and Greenberg 1994). Karon (1989) states that this phenomenon is so robust that it seems to work no matter which measure is used. Most authors attribute the concept of the alliance to Greenson, but many use alliance concepts without apparent awareness that they have their origin in psychoanalytic theory and technique. For instance, Heinssen, Levendusky, and Hunter (1995) describe the program of "therapeutic contracting" developed by Levendusky and his colleagues at McLean Hospital that secures compliance with treatment plans by concentrating on forming an "effective alliance with clients" (p. 523). Among the forty-six references cited at the end of their report, not a single psychoanalytic work appears, though the concepts employed clearly derive from psychoanalytic thinking. Yet the concept has been extruded from mainstream American psychoanalysis since 1980 and has not figured at all for psychoanalysts in the rest of the world.

Concepts come into favor and fall out of it for many reasons. Spence (1982) detailed many of the nonscientific (that is, political) reasons for the waxing or waning of ideas. In the case of the therapeutic alliance, we think the reasons are both empirical and political. As we trace the genealogy of the concept of alliance and note the centrality of the issues that are touched on in considering the theoretical and technical questions involved, it becomes clearer why the alliance concept has become an area of controversy and criticism, partisanship and polarization.

The alliance has always involved examination of the treatment relationship, but Zetzel's and Greenson's work brought this aspect into the foreground. J. Novick (1970) noted that Greenson's definition of the alliance as based on the real relationship between patient and analyst led inevitably to changes in classical technique and the introduction of interventions that went beyond what was then considered acceptable (Eissler 1953). Zetzel and Greenson were writing at a time in American psychoanalysis when relationship issues were seen as a threat to the established view of proper classical psychoanalytic technique. The theoretical distinction between psychoanalysis and psychotherapy had been established on the basis of the modifications of technique used in psychotherapy. These modifications included active use of the relationship to support, suppress, alter, or manipulate the patient's behavior, rather than to interpret underlying conflicts. At the root of this distinction had been the controversy over the work of Alexander (1950, 
1956; Alexander and French 1946), who advocated a therapy aimed at corrective object relations, rather than interpretation of the tranference relationship. Curtis (1979) ended his reasoned critique of the alliance concept by pointing to the danger "in the tendency to see the therapeutic alliance as an end in itself-to provide new and corrective object relationship - rather than as a means to an end of analyzing resistance and transference" (p. 190).

How these theoretical concerns touched on politically delicate issues can be further understood when we note that Greenson and Wexler's "working alliance" concept (1969) was delineated in the context of a political and personal struggle between Greenson and Leo Rangell, then the two most eminent psychoanalysts in Los Angeles, but two very different personalities, with differing theoretical allegiances. Rangell, who has served as president of both the American Psychoanalytic Association and the International Psychoanalytical Association, felt he represented the established order in theory and technique. Greenson was considered a major figure, a brilliant teacher, lecturer, and expositor. But, at the same time, he and Wexler were part of a Hollywood scene, analysts to the stars, and were increasingly using unorthodox techniques, which became an embarrassment to classical analysts. When Curtis (1979) wrote of the danger that the alliance or relationship would become an end in itself, he was probably referring not only to Alexander's technique but also to the style of relationships fostered by Greenson and Wexler with their film star patients. These analysts rationalized practices that went considerably beyond standard technique then or even now. Greenson's papers on the working alliance appeared soon after the ambiguous death of his patient Marilyn Monroe; his emphasis on the real human relationship could not but be read in the context of a treatment that included virtually adopting his famous patient. Farber and Green (1993) describe that treatment in detail and quote Rangell as saying to them, "This was seductive behavior, not therapeutic behavior" (pp. 108-109). Similarly, Wexler collaborated with a patient on a screenplay and enlisted his patients in fund-raising efforts for his foundation for the study of hereditary diseases. Despite the undisputed value of the work of the foundation, Wexler's use of the therapeutic relationship for purposes outside the aims of the treatment and beyond the needs of the patient raised grave questions of manipulation of the transference. Thus, the extrusion of the concept of therapeutic or working alliance from mainstream American 
psychoanalysis must be understood in part as a response to a perception of dangers inherent in a focus on the "real relationship."

These political and ethical concerns colored the empirical examination of the usefulness of a concept that encompasses important dimensions of the therapeutic relationship. In particular, from its beginnings in Freud's formulations through to the work of Greenson and those who espoused his conception, the alliance between patient and analyst has been seen in terms of issues of an interpersonal relationship. Brenner, Curtis, Kanzer, Novick, and others cogently criticized the idea that transference and the alliance are separate domains, each requiring different approaches, with interpretation reserved for the transference, and the alliance requiring separate methods to strengthen and support the real, human relationship between doctor and patient. These justified criticisms, together with the consolidation of classical technique, served to banish the concept of therapeutic alliance, but with it, perhaps unwittingly, was lost the possibility of examining the relationship that serves as context for all our techniques.

Now that classical technique is itself under attack, we might expect a reemergence of the alliance concept. Instead, however, we see a rediscovery of the relational aspects of treatment and a tendency to focus on them. Much of this emphasis is a result, direct or indirect, of the influence of British object relations theories. Because alliance elements are built into their fundamental constructs, these theories never had a place for an explicit alliance concept. Grotstein (1990) called Winnicott a "master of the therapeutic alliance" (pp. 6-7), even though Winnicott never wrote about it as such. But he did write extensively about the holding and facilitating environment of the treatment, about ego needs and id desires (Winnicott 1965). Other theorists speak to elements of the therapeutic alliance in various terms, such as "the container" (Bion 1977), "projective identification" (Klein 1946), "coverage" (Khan 1974), the "new beginning" (Balint 1968), and the analyst as "transformative object" (Bollas 1987). To the British object relations theorists, transference and countertransference have always been broader, more elastic concepts than their counterparts in the Viennese/American classical tradition, and deeper in their putative capability of reflecting the earliest mother-child relationship. At a time when American psychoanalysis was focusing primarily on the development of a general psychology (Hartmann, Kris, and Loewenstein 1964; Rapaport 1960), European psychoanalysts were turning to investigation of the clinical process. 
The successful extrusion of the alliance concept from mainstream American psychoanalytic technique created a vacuum that has been filled by relationship theories based on the work of the British analysts cited above and those following them, theories ranging from Kohut's emphasis on self-object transferences and empathy $(1971,1977)$ to Greenberg's formulation (1995) of the "interactive matrix" as the "third step in the evolution of our thinking about method" (p. 11). The dismissal of the alliance concept as ambiguous, specious, or dangerous deprived classical mainstream theory of a conceptual vehicle for the integration of relational and cognitive-affective components of analysis. This allowed the emergence of divergent schools created in opposition or reaction to a technique seen as sterile, inhumane, and incompatible with an object-relational, interpersonal, or intersubjective two-person psychology.

An argument could be made that the concept of the therapeutic alliance is by now of historical interest only, that it arose early and could not be integrated into the corpus of clinical theory, and that it is now superseded by theories able to deal with the issues previously covered by alliance concepts. Our survey of the history of the alliance concept demonstrates, however, that it emerged as part of the shift from an id psychology to equal emphasis on the ego. As such, it provided the possibility of amalgamating relational ideas and a focus on ego development and functioning. Scrapping the alliance concept leaves a vacuum to be filled by relationship theories that oppose ego psychology and maintain what Freud (1928) termed the "mystical character" of tact (p. 271). We then also risk the loss or disuse of the vast store of clinical knowledge and generative concepts found under the rubric of classical ego psychology.

Despite the expunging of the therapeutic alliance from the glossary of politically acceptable terms by the majority of psychoanalysts, some have continued to find it an important theoretical and technical concept (Blum 1981; Fine 1979; Meissner 1992, 1996; Rawn 1991; Sandler, Dare, and Holder 1973; Sandler and Sandler 1994). We too have found the alliance concept necessary, particularly when we have attempted to make sense of complex clinical phenomena in apparently very different areas of theoretical exploration. Our studies of termination (J. Novick 1976, 1982a,b, 1988, 1990, 1997; J. Novick and K. Novick 1992, 1996b) describe the therapeutic alliance as a crucial indicator during the pretermination phase of readiness to start a termination phase, and 
as a central factor in an adaptive response to termination. The capacity for self-analysis, currently formulated as a major goal of analysis itself, can be understood as a result of the accomplishment of therapeutic alliance tasks. Our work on sadomasochism, omnipotence, and externalization (K. Novick and J. Novick 1987; J. Novick and K. Novick 1991, 1992, 1996a,b) led to our formulation of the alliance tasks at each phase of treatment as highlighting the conflict between the demands of each task and the resistances of sadomasochism. Our continued need for and sense of the utility of an alliance concept has led us to a revised theory of the therapeutic alliance (K. Novick 1991; J. Novick 1991, 1992, J. Novick and K. Novick 1994,1996b).

In our revised concept of the therapeutic alliance we attempt to integrate the contributions of the many theorists who have grappled with the issues involved.

Like Freud (1912), Fenichel (1941), and Zetzel (1956), we include transference as a motive for the alliance.

Like Freud (1928) and Ferenczi (1928), we assign weight to the therapist's active use of empathy and tact to establish an alliance.

Like Bibring (1937), Sterba (1934), Anna Freud (1965), and others, we see the alliance as a collaboration with the ego of the patient.

Like Freud (1940), Ferenczi(1928), Sterba (1934), Stone (1954, 1961), Loewald (1960), Balint (1968), Greenson (1971), Gill (1991, 1995), Greenberg (1991, 1995), Renik (1993, 1995), and others, we include as integral to a concept of the therapeutic alliance the view expressed by Anna Freud (1954) that "somewhere we should leave room for the realization that analyst and patient are also two real people, of equal adult status, in a real personal relationship to each other" (p. 373).

Like Nunberg $(1928,1932)$ and Langs (1975), we include unconscious motives, both negative and positive, in the maintenance and functioning of the alliance.

Like Bibring (1937), Winnicott (1965), and Anna Freud (1965), we include the fulfillment of ego needs among the motives for the alliance.

Like Langs (1975) and Weinshel (1984), we see the alliance as unstable and susceptible to the forces of resistance and conflict.

Like Zetzel (1956), Schlessinger and Robbins (1983), and Tahkka (1993), we see the alliance as drawing on early parent-child interactions; thus, all developmental issues are crucial to the formation and maintenance of the alliance. 
Like Gitelson (1967) and Etchegoyen (1991), we find that the alliance is at its most efficient during the termination phase of treatment; like Schlessinger and Robbins, we have found that it becomes internalized as a self-analyzing function available on follow-up.

Like Hanly (1994), we find that the alliance is a necessary, but not sufficient, agent of therapeutic change.

Like Brenner (1979), Curtis (1979), Kanzer (1979), Weinshel (1984), and Hanly (1994), we do not think that the alliance occupies a separate domain requiring techniques other than the classical.

Like Freud (1913), Ferenczi (1928), Sterba (1934), Bibring (1937), Hanly (1994), Etchegoyen (1991), and others, we see the alliance as requiring the active intervention of the analyst, becoming consolidated and increasingly available through the work of the analysis, not available sui generis from before the beginning of treatment.

We have found it heuristically useful to apply the developmental point of view to the course of treatment. It has allowed us to think of psychoanalysis in terms of phases, therapeutic tasks, and assessment of their accomplishment - that is, the outcome of therapeutic interventions at any given point in the treatment. Thinking about what goes on in treatment in terms of "tasks" has a long history in psychoanalysis. Such thinking could even be said to mark the beginning of psychoanalysis, with Freud's shift from an authoritarian medical model of hypnotic suggestion to the assignment of the task of free association to the patient (Breuer and Freud 1893-1895; Freud 1900). It springs also from Erikson's work on the life cycle, which has had a lasting impact on developmental theories. Erikson (1950) expanded Freud's idea of psychosexual developmental phases into the "eight stages of man" (pp. 219-234), each with its own particular organ modes, social modalities, and nuclear conflicts. At each stage the ego is faced with the task of finding a solution to that conflict. Whenever we have written on development, we have used the idea of tasks in relation to universal conflicts specific to particular phases-for instance, the early adolescent task of ownership of the sexual body (K. Novick and J. Novick 1994a).

Inherent in Erikson's theory of the life cycle, Freud's psychosexual stages (1905), and Anna Freud's developmental lines (1965) is the idea of direction. All child analysts explicitly or implicitly use developmental goals as standards in their diagnoses, assessments, treatment plans, and termination decisions. Applying developmental concepts to the process of therapy, one can speak of phases of treatment, from the 
evaluation and beginning, through the middle and pretermination phases, to termination and follow-up. We do not, as Zetzel did, see these treatment phases as recapitulating actual developmental phases but, rather in the mode of Erikson, speak of each treatment phase as having its own nuclear conflict that is experienced by everyone. The patient's ego has the task of solving that conflict. How it is solved reveals particulars of the individual patient's history and current functioning, and how the analyst responds varies with the skill, training, and orientation of the individual analyst. But in each phase everyone is faced with the same conflict. For instance, at evaluation a major task is to resolve the conflict between being and not being a patient; at the beginning of treatment the conflict is about being with or not being with the therapist; and so on through the phases of treatment. Mutual engagement around these tasks can become a major fulcrum for therapeutic change and regaining developmental momentum.

In an earlier publication (K. Novick and J. Novick 1994b) we said that using the alliance concept allows the locus of experienced difficulties to be shifted from external events to the treatment itself. Here we would add that looking at the therapeutic relationship through the lens of the therapeutic alliance explicates and operationalizes analysis as a developmental experience. Meissner (1996) states this clearly: "The therapeutic alliance has profound implications for the outcome of therapy, providing a matrix within which important interpersonal experiences and crucial identifications, which may modify the patient's pathogenic inner structure, can take place" (p. 7). Earlier we noted that the idea of phases of psychoanalytic treatment began with Freud, but it was Glover (1955) who specifically delineated beginning, middle, and termination phases. We have also referred to the understandable reluctance of analysts to schematize something so individual as the course of an analysis; nonetheless, we have suggested that "if we keep in mind that the phases of treatment are not mutually exclusive, nor are they mechanical checkpoints in a sequence, then the schema can be useful for highlighting certain tasks, resistances and techniques" (J. Novick and K. Novick 1996b, p. 364). Keeping this in mind, as well as our further emphasis that each highlighted alliance task persists through each and all of the other phases of treatment, readers may find the accompanying chart a useful organizer of these ideas. Thus, we have found that we can operationalize the alliance aspects of the therapeutic relationship in terms of the tasks that face each and every patient and 
THERAPEUTIC ALLIANCE TASKS

\begin{tabular}{|c|c|c|c|c|c|c|}
\hline & $\begin{array}{c}\text { Evaluation } \\
\text { Phase }\end{array}$ & $\begin{array}{l}\text { Beginning } \\
\text { Phase }\end{array}$ & $\begin{array}{l}\text { Middle } \\
\text { Phase }\end{array}$ & $\begin{array}{l}\text { Pretermination } \\
\text { Phase }\end{array}$ & $\begin{array}{l}\text { Termination } \\
\text { Phase }\end{array}$ & \begin{tabular}{|c|} 
Posttermination \\
Phase
\end{tabular} \\
\hline Patient & $\begin{array}{l}\text { Bring material, } \\
\text { Engage in } \\
\text { Transformation } \\
\text { tasks }\end{array}$ & $\begin{array}{l}\text { Being with } \\
\text { therapist }\end{array}$ & $\begin{array}{c}\text { Working } \\
\text { together } \\
\text { with therapist }\end{array}$ & $\begin{array}{l}\text { Putting insights } \\
\text { into action } \\
\text { Independent } \\
\text { therapeutic work } \\
\text { Maintain progres- } \\
\text { sive momentum }\end{array}$ & $\begin{array}{c}\text { Setting aside } \\
\text { infantile fantasies } \\
\text { Internalization of } \\
\text { alliance } \\
\text { Mourning }\end{array}$ & $\begin{array}{l}\text { Use alliance } \\
\text { skills for living } \\
\text { and creativity }\end{array}$ \\
\hline Therapist & $\begin{array}{l}\text { Initiate } \\
\text { transformations of } \\
\text { (a) self-help to } \\
\text { joint work } \\
\text { (b) chaos to order } \\
\text { and meaning } \\
\text { (c) fantasies to } \\
\text { realistic goals } \\
\text { (d) external } \\
\text { complaints to } \\
\text { internal conflicts }\end{array}$ & $\begin{array}{c}\text { Feeling with } \\
\text { patient }\end{array}$ & $\begin{array}{l}\text { Maximum use of } \\
\text { ego functions }\end{array}$ & $\begin{array}{l}\text { Allow for patient's } \\
\text { independent } \\
\text { therapeutic work }\end{array}$ & $\begin{array}{l}\text { Allow patient's } \\
\text { mourning } \\
\text { Deal with } \\
\text { own loss } \\
\text { Analyze to end }\end{array}$ & $\begin{array}{c}\text { Stay available } \\
\text { as analyst }\end{array}$ \\
\hline $\begin{array}{c}\text { Parents or } \\
\text { Significant } \\
\text { Others }\end{array}$ & $\begin{array}{l}\text { Engage in } \\
\text { and allow } \\
\text { transformations }\end{array}$ & $\begin{array}{l}\text { Allow the } \\
\text { being with }\end{array}$ & $\begin{array}{c}\text { Allow for } \\
\text { individuation or } \\
\text { psychological } \\
\text { separation }\end{array}$ & $\begin{array}{c}\text { Enjoy and validate } \\
\text { progression }\end{array}$ & $\begin{array}{c}\text { Mourning loss of } \\
\text { therapy } \\
\text { Internalizations of } \\
\text { alliance } \\
\text { Consolidation in } \\
\text { phase of parenthood }\end{array}$ & $\begin{array}{c}\text { Allow contin- } \\
\text { ued growth } \\
\text { Grow with } \\
\text { patient }\end{array}$ \\
\hline
\end{tabular}


analyst throughout their work together. What is unique about each treatment is what each partner brings to bear on these tasks and what they create together in the attempt to resolve the conflicts.

In an earlier paper (K. Novick and J. Novick 1994b), we suggested a number of general principles regarding our revised theory of the therapeutic alliance, which we will summarize here. We will then apply them to understanding the operation of resistances based on sadomasochistic pathology.

1. The concept of the therapeutic alliance is like a lens that highlights certain features of the material. It is the same material whichever lens is used.

2. It is important to distinguish between the capacities necessary for an alliance and the motivation to use those capacities for mutually agreed-upon therapeutic goals.

3 . The therapeutic alliance is motivated by rational and irrational forces, by negative and positive aims, and by past and current wishes.

4. The therapeutic alliance is not stable but varies at different stages of treatment and with each successive emergence of a conflict and its object, affective, and drive components. The fluctuations of the alliance enable the therapist to see, share, and interpret conflict, defense, anxiety, and transference in a way the patient, even a young child, can understand. Fluctuations in the alliance may be used as indicators of conflict, resistance, and change.

5. The responsibility for initiating a therapeutic alliance lies with the therapist.

6. Each treatment phase has its particular alliance tasks.

7. The therapeutic alliance should eventually become an equal partnership between analyst and patient.

8. The therapeutic alliance is a relational concept; as such, it requires input from all parties. The alliance does not reside in any party alone, but is a joint creation in the analysis. Despite the current polarization, we feel there is no inherent incompatibility between relational and cognitive/affective techniques. Indeed, we believe that a revised theory of the therapeutic alliance can bridge the gap between these two approaches. Equally, attempts to integrate empirically derived attachment theory with clinical work can be said to fall into the domain of the therapeutic alliance. 


\section{IN SEARCH OF A DEFINITION}

From our review of the history of the alliance concept, we conclude that much of the difficulty has come at the point of trying to define the alliance. Various attempts have created untenable dichotomies, contained clinically inaccurate propositions, idealized either analyst or patient, and generally reduced the richness of the experience of treatment to an unrealistic simplicity. However, some writers, both proponents and critics of the alliance concept, have acknowledged the dynamic complexity of alliance phenomena (Weinshel 1984; Meissner 1992, 1996). In speaking of the therapeutic alliance, we have used the metaphor of a lens in order to emphasize that the alliance is a way of looking that highlights certain aspects of the whole analytic process. When we liken the alliance to a lens, we emphasize that the therapeutic alliance is a concept, to be evaluated by its utility rather than by its reality. The alliance has no more nor less existence than other technical concepts; each moment in treatment, from the first phone call to the last goodbye, can be looked at through the lenses of transference, defense, resistance, real relationship, ego needs, new developmental object, id desires, and therapeutic alliance. Each highlights certain aspects of the clinical field. For example, the lens of transference highlights motives and desires in the patient, providing both a description of the source of a current object representation and a genetic explanation for its persistence, whereas the alliance lens highlights the motives and capacities for collaborative work on certain tasks by both patient and analyst.

This formulation is consistent with the unique psychoanalytic approach to data. Psychoanalysis emphasizes simultaneous multiple points of view - that is, metapsychology — rather than the mutually exclusive, dichotomous categorization of other disciplines. Thus, the therapeutic alliance and the transference and the real relationship are not in opposition to each other; rather, each complements and elucidates the others. Only a definition that retains the assumptions of metapsychology can reflect the complexity of mental and interpersonal functioning. Perhaps, then, some of the difficulty in arriving at a definition lies in the attempt to describe the therapeutic alliance as "out there" in the patient, rather than to characterize it as an "in-between" clinical concept that gives us additional powers of perception. We suggest the following as a useful formulation: the therapeutic alliance is a way of looking at the entire clinical field, a lens, that allows for heightened 
attention to the capacities and motivations, conscious and unconscious, from all levels of the personality and all stages of development, that enter, for both patient and analyst, into the specific collaborative tasks of each phase of treatment, to the resistances and conflicts that arise around these tasks, and to the therapeutic change in motivation during the course of analysis.

\section{THERAPEUTIC ALLIANCE TASKS AND THE PHASES OF TREATMENT}

As we now describe some of the analytic work with Mrs. T, we will use our ideas of the therapeutic alliance tasks of each phase of treatment to highlight resistances arising out of the sadomasochistic aspects of her pathology and the omnipotent fantasies that were found to be at the core of her disturbance. The mind is so complex and variable, so difficult to encompass, that it is not surprising that patients and analysts may seek a simple way to understand, in such ideas as a core fantasy, a central complex, a paradigmatic tranference, the major set of resistances, or the traumatic event. We would like to emphasize that our intent is not to simplify, but rather to enrich our understanding of the complexity, to add to our capacity to see. What follows is an account of five years of rich analytic work, sketched here through only one of the available lenses, that of the therapeutic alliance.

\section{Evaluation Phase}

Mrs. T was a successful businesswoman, married, with three grown-up children. She had felt depressed and somewhat empty for a long time, and consulted a psychiatrist, who recommended an antidepressant. Mrs. T was disinclined to use medication, as she felt her friends on pills had lost their zest, even though they claimed to be very happy. So she sought out an analyst, with the idea that he would prescribe analysis. The analyst was tempted to think of Mrs. T as a very sensible, enlightened person. Analysts are not always in the habit of thinking of expressed positive wishes for treatment as a possible resistance, but in this case the analyst paused mentally to assess the status of the evaluation in the light of the appropriate therapeutic alliance tasks - that is, in relation to various transformations that should be started before treatment proper begins. Through this lens it became clear that Mrs. T had not begun to shift to the idea of joint work, had 
not addressed her fantasies around being told what to do by an expert, and was still dealing with her problems as external-patient and analyst had not yet arrived together at a sense of internal conflict in her. This indicated that more work was necessary in the evaluation. The analyst pointed out to Mrs. T that she seemed to be seeking another expert opinion from him to make her decision. She replied that this was the secret of her success - she had never had to make decisions, but had been pushed throughout her life by circumstances and other people's ideas about her. The analyst wondered about this pattern as a source of difficulty, noting that it implied that she had no wishes of her own, that she had never pursued a desire from inside herself. This first verbalization of elements of conflict produced new material. Mrs. T described a number of affairs she had had at conventions in faraway cities and said that she had never told anyone about these before. The analyst could then discern Mrs. T's conflict over her sexual impulses. Rather than interpret at this point on the basis of the content, about which little was yet known, the analyst noted to himself the auguries of erotic transference in this material, and chose first to take up the way Mrs. T's own wishes could be met only with built-in limits and in secrecy. He suggested that understanding this would be something they could work on together. Mrs. T remarked thoughtfully that she would like to be able to feel good more of the time, not only during those brief, secret affairs, and that maybe this problem was what her depression was about. Thus, the analyst and Mrs. T were able to arrive together at an explicit goal for her treatment.

Through the course of the analysis, the pervasiveness of Mrs. T's sadomasochistic character pathology emerged ever more clearly, as the "secret of her success" could be understood as a variant of a fixed beating fantasy with the omnipotent delusion that by creating a victimized, slave relationship Mrs. T could secretly fulfill all her desires. Since early childhood, all her behavior and thoughts, as well as her sexual life, were organized around a fantasy of being forced by others or by circumstances to do things. She claimed to have no goals or desires, except the need to be perfect. She lived in a world devoid of pleasure, joy, or creativity, except for limited moments of stolen illicit pleasure, as in her brief affairs. As the analysis progressed, it became clear to Mrs. T that what had been diagnosed as depression was her sadomasochistic need to live in a world of psychic and physical pain in order to feel safe, connected, and powerful. Looking at the material of the evaluation phase through 
the lens of transference highlights Mrs. T's gratification in sadomasochistic relationships. The lens of the therapeutic alliance, however, reveals her conflicts over allowing other sources of pleasure. This was the gateway to further work on elucidating two systems of self-esteem regulation in her personality. At the evaluation phase Mrs. T and the analyst shared the joint acknowledgment of her serious problem in the area of pleasure; on this basis, her analysis began.

\section{Beginning Phase}

Mrs. $T$ attended regularly and punctually, reporting in conscientious detail the events of her life, but a pattern began to emerge in which she presented material and left it to the analyst to make something of it. The analyst's occasional remarks (for instance, about Mrs. T's relationships with fellow workers) were accepted, but Mrs. T never seemed to take them further. In the beginning phase of treatment, the patient's therapeutic alliance task is to be with the analyst; the analyst strives to feel with the patient. The therapist intervenes actively when obstacles to being together arise in the patient, from the environment, or from the therapist. These tasks of being with and feeling with persist throughout treatment but predominate at the beginning. With these tasks in mind, Mrs. T's analyst began to understand her apparent compliant passivity as her way of being with him. Mrs. T's conditions for the relationship included externalizing her ego capacities for reflection and integration onto the analyst to create a sadomasochistic transference that cast her in the role of a naive child sitting at the feet of a wise elder. As the images in her material brought this relationship into sharper focus, the analyst pointed out how rarely Mrs. T seemed comfortable with the idea that they were two adults working together- that is, he interpreted the interference with the alliance task. Mrs. T exclaimed, "Why come at all if you won't do it?" She said that she was sure that she could eventually force him to take care of her and decide everything for her if she only waited it out and did as she was told. This harked back to the initial push from the patient to have an expert tell her what was wrong with her and what she should do about it. The analyst had used the therapeutic alliance task of being with another as a lens to help him see clearly the dimensions of the sadomasochistic transference as it was emerging; when this was taken up with Mrs. T, an underlying omnipotent fantasy of control emerged and became accessible to the work of the analysis. 
Together Mrs. T and the analyst began to explore why she needed to establish a sadomasochistic way of being with him. This effort produced moments of rage and panic in Mrs. T. She reported staying awake at night, feeling unable to think whenever she tried to imagine herself as the analyst's equal and resenting his demands on her. "I don't know what makes you think I can do any of this," she snapped, "and what would really happen if I did? What would you really feel?" Mrs. T's fear of the analyst's reaction led to memories of her mother, a person of low intelligence who had barely finished grade school. Depressed throughout Mrs. T's childhood, she had always become extremely defensive whenever Mrs. T won a school prize, demonstrated any competence at home, or simply looked attractive. Through the lens of the alliance task of being with the analyst, Mrs. T's conflicts over being herself in a relationship were illuminated and brought explicitly into the transference relationship. With continued attention to Mrs. T's externalizations of ego functions, she gradually became more involved in the analytic work, making spontaneous observations and at times associating to her dreams without prompting. The workings of her own mind were gradually becoming an object of her curiosity.

\section{Middle Phase}

This marked her transition into the middle phase of the treatment. The therapeutic alliance task of this phase is working together. The patient's mind becomes an object of inquiry, and we begin to track fluctuations in the patient's willingness to engage in the work, via attention to ego functions of both patient and analyst. At times it was painfully difficult for Mrs. T to reflect, expand, associate, or explore her ego functioning. Sometimes when she brought a dream, she struggled to associate to it. Her mind, she explained, seemed to "shut down." As she and the analyst focused on this selective shutdown, Mrs. T gradually began with a few associations to her dreams, but then immediately became intensely self-critical. Acknowledging her transference fear of being humiliated, with its roots in her history of being teased, brought some relief but did not solve the problem, as the source of the humiliation was by that time lodged in her own ego ideal, her own demand that she be always right, that she be perfect or go away and practice in secret until she became so: "I will not tolerate mediocrity in myself. I have to be perfect or work on it until I am." Being right meant being big, powerful, and in control of others. All comments or interpretations implied that 
she was wrong, and she felt like a helpless, defective child. She was in the throes of a full-blown sadomasochistic transference. Working together is incompatible with sadomasochism. A serious therapeutic impasse threatened, but Mrs. T found a way out through her stories.

In the course of treatment Mrs. $\mathrm{T}$ had developed an interest in writing stories, had enrolled in a number of writing classes, and then began sharing the stories in her sessions, sometimes reading drafts or sections to the analyst. At no time did she expect or ask for a literary critique, but explicitly used the stories to explore further the inner lives of her characters. For quite some time the analyst made no link between any particular character and the patient, but sometimes, in relation to a particular facet of a character's personality, the patient would say, "That's like me." This continued for about a year, during which time the stories changed considerably. A few were published. The analyst, occasionally concerned that the treatment had turned into a literary seminar, had moments of doubt, but generally trusted a feeling of momentum generated by the joint attention made possible by the focus on fictional characters. Patient and analyst were working together, even if the focus was not always obviously analytic. Through the lens of transference, the analyst understood Mrs. T's use of the stories as a hostile defensive resistance to direct experiencing of positive transference. It was also clear, however, that any attempt to take that up was turned by Mrs. T into a sadomasochistic control battle. Focus on the alliance perspective allowed for space to work together on understanding the stories, and for Mrs. T to discover a potential source of self-esteem in feelings of competence and effectance from the work, rather than from controlling the object. She began to track patterns of fluent thinking, constrictions, and fuzziness, which were noted and then altered and mastered. From a developmental perspective, this part of the analysis resembled child work, where a play space is established that allows for talking about and working on conflicts first in displacement, as in doll play or games.

Mrs. T reported a dream and noted that this was her first dream in over a year. She was on stage and getting ready to perform the Mozart clarinet concerto. Suddenly she began to panic, afraid she would forget everything. Then she looked toward the wings and saw her old teacher from childhood, who smiled at her; then she felt calm and confident. She associated to the fact that the clarinet had been her choice of instrument in junior high school, but her mother, who had loved the piano, disapproved and always covered her ears when her daughter practiced. 
Mrs. T said to the analyst, "The old clarinet teacher is you, and I want to thank you for being so patient and listening to me practice. I'm ready to share my own story with you now."

From that point Mrs. T was able to address her conflicts over her own wishes, as well as the anxiety about her creative expressions that had led to her crippling emotional constriction and depression. She grappled bravely with her vulnerability to a pervasive dissatisfied mood. At such times, her tone of voice was nagging or disconsolate, as she had a painful sense of falling short. Nothing inside or outside was ever quite good enough. The analyst sometimes felt the impulse to contradict or reassure her, rather than to work analytically, following associations and reflecting together on their form and content. These departures from the joint capacity to work together alerted him to a recurring resistance. The content could then be discerned more easilyMrs. T spoke as if she would be satisfied only with perfection. Here was an omnipotent fantasy underlying the pervasive sadomasochistic interference with the pleasure economy. Working together is a mixed experience that brings great satisfaction in the process and achievement of understanding, and carries with it inevitable disappointments at limitations in insight, difficulties in communication, and transient dyssynchronies between patient and analyst. This task of the therapeutic alliance thus stands in direct contradiction to the delusional image of a perfect communion that Mrs. T strove for. Thus, therapeutic alliance issues highlighted the transference reenactment of Mrs. T's problematic relationship with her disturbed, remote mother and her conflicts over the meaning of her striving for perfection in her work and family life. Her mother's dissatisfaction with her seemed controllable if she blamed her own imperfections for her mother's hostility and vindictiveness; perhaps if she were perfect she could make her mother respond positively.

Working effectively together provides intense satisfaction that draws first on all the accumulated transformations of early experiences of attunement. Second, working well provides an experience of competence that stands in contrast to a closed sadomasochistic system of pleasure from fantasies of omnipotent control over others. Realityoriented satisfaction motivates further collaborative work. The pleasure of accomplishment of the alliance task of working together leads to internalization of dialogue and exploration and nourishes creativity, with its accompanying feelings of joy. Repeated experience of 
pleasure from competence is necessary to the patient's developing a conflict between different ways of regulating self-esteem.

During the middle phase, variations in the analyst's ego functioning and associated affects could also be used to track the pattern of the therapeutic relationship. The analyst could differentiate within himself the quiet sustained pleasure of joint work; joy in watching Mrs. T's growing capacity for creative insights; boredom and distraction when Mrs. T withdrew into an omnipotent pseudoindependent stance; and the mixture of gratification and discomfort when Mrs. T externalized her own ego functions and turned the analyst into a perfect god. The analyst used these reactions to define the quality of the alliance and explicitly made the alliance tasks a joint responsibility.

\section{Pretermination Phase}

By tracking fluctuations in their joint and separate motivations to work together, Mrs. T and the analyst became increasingly skilled at quickly spotting regressions to externalizing transference, sadomasochistic patterns of relationship, and manifestations of omnipotent hostile fantasies of control and perfection. Mrs. T took on greater responsibility for self-reflection and observation of the analytic process, and in her life outside the analysis she was experiencing pleasure and satisfaction in all areas, which led the analyst to notice his own occasional thoughts that she seemed to be moving into a pretermination phase. Although she continued to report excellent functioning outside, Mrs. T made no mention of termination and the sessions became more and more emotionally arid. The analyst found himself musing, occasionally sleepy, and vaguely impatient. Mrs. T began to talk about the financial burden of the analysis and suggested that there was "really nothing more going on here." She thought it was time to stop. The analyst was taken aback by her proposed manner of ending. His sense of the therapeutic alliance tasks of termination, which include the setting aside of infantile fantasies, the internalization of the alliance, and a mourning of the relationship to the treatment and the analyst, helped him see that Mrs. T was seeking a premature termination. He talked with Mrs. T about the factors that go into deciding to begin a finishing time. One important element is the patient's feelings about the relationship with the analyst-if Mrs. T had already withdrawn emotionally, it was as if there were nothing left to say goodbye to. Mrs. T said angrily, "I've never been left by anyone before, so I'll 
make sure this is not the first time!" This allowed for interpretation of Mrs. T's avoidance of sadness by preemptive control. Her anxiety and need to control betrayed her fear of sadness over the loss of an experience and a relationship that were really important to her. She was afraid of having real feelings that were not as predictable as her unhappiness or numbness could be. Those she could control, just as she had tried to control other people, including the analyst, by provoking ill treatment in her relationships. Mrs. $\mathrm{T}$ and the analyst regained joint work and mutuality in characterizing her conflict between love and power. Again the lens of the therapeutic alliance task highlighted a sadomasochistic interaction; interpretation in terms of alliance issues revealed the underlying omnipotent fantasy of emptying the analysis of dynamic activity in order to provoke the analyst to kick her out. She could then be angry with him and avoid feeling helpless in the face of her sadness. After this attempt at premature termination, Mrs. T regained affective involvement in her analysis and resumed responsibility for the momentum of the work.

In anticipating with patients the integrating and consolidating work of the termination phase, we include the need to ensure there are no remaining secrets or pockets of unexplored issues that have not been worked on together. Genuinely independent work cannot take place unless the patient has become capable of sharing and working together on everything. Mrs. T's accomplishment of the pretermination therapeutic alliance task of taking responsibility for her analytic work had to feel solid before the decision to enter a termination phase could be finalized. She had mentioned in passing that she had met an interesting man at work. Alerted by a slowing in the pace of the therapeutic work, and the sense that Mrs. T had again withdrawn emotionally from the therapeutic relationship, the analyst asked about Mrs. T's thoughts of the man she had mentioned. Mrs. T revealed that she was having fantasies of an affair. As they explored her associations, the analyst reminded her that they had understood her previous affairs in terms of her conflicts over expressing her wishes. In relation to thinking of termination, the recurrence of thoughts of an affair not only represented a displacement of feelings about the analyst but also carried Mrs. T's fears that her intense feelings would get out of control. By directing her feelings outward to an alternative object, Mrs. T felt she was protecting the analyst. They came to understand that such fears masked an omnipotent delusion that only her self-restraint controlled 
the interaction between her and the analyst. With this material, Mrs. T was better able to own her real feelings, with their realistic limits, and think about choosing a date for termination.

When it came to picking a date for termination, Mrs. T again regressed to a sadomasochistic transference. She insisted that the analyst should decide, with a fantasy that he was treating her unfairly. Then she would be justified in her anger and could fight with him and storm out of treatment. The analyst recalled what they had learned about her wish to control feelings between them in order to avoid the pain of mourning. He interpreted Mrs. T's using a sense of victimization to retain power. She brought in a dream of a nuclear holocaust. Associations led to her conviction that her feelings might annihilate them both, that the analyst would be blasted into the void of space after termination unless she retained her hold on the situation by making him a failure. This was her delusion of omnipotence, that she could keep the analyst alive, as transference mother, by locking them both into an angry sadomasochistic stalemate. The session after this interpretation was on a sunny, breezy day. Mrs. T came in smiling ruefully and remarked as soon as she settled on the couch that she had noticed the lovely morning. She was remembering the several springs that had passed during her analysis, and realized that she had only recently begun to even notice the smell and the soft air. She had been thinking that she and the analyst had been through lots of hard times together, but she couldn't deny that there had also been some good times. It had occurred to her that she had to give the analyst credit for his contribution if she were going to take credit for hers. This acknowledgment contained her realization that the analyst was a separate, autonomous person whose thoughts and feelings were not under her control. It also was evidence of her recovered capacity to work independently, a milestone alliance achievement of the pretermination phase. Mrs. T was able to choose a date a few months hence, and the termination phase began.

\section{Termination Phase}

During the termination phase the therapeutic alliance functions at peak efficiency, but omnipotent fantasies are also at a peak, in a lastditch attempt to retain sway in the functioning of the personality. In her struggles over her sadness, Mrs. T would slide into self-pity, presenting herself as a helpless person, with the fantasy that she could make the therapist keep her after all if she were a mess. She also described herself 
as "depressed" whenever she was angry at the constraints of reality, particularly at the inexorable progress of time toward the termination date. Mrs. T again began to have daydreams of starting a relationship with the man at work, who from her descriptions sounded like a sadistic, controlling person. The analyst pointed out that she was contemplating continuing a relationship of power and control, and wondered what Mrs. $\mathrm{T}$ felt would happen if she gave up that pattern of interaction with others. "Somebody has to stay in charge!" Mrs. T exploded.

Several days of intense anger and anxiety followed her outburst. She telephoned the analyst, saying that she thought she should be put on medication. The analyst noted that her presentation of herself as incompetent had not pushed him to change the termination date, so she seemed to have upped the ante with her insistence that her feelings were so powerful that no one could control them. It seemed like a temper tantrum. The analyst remarked on how she was using her feelings to bully and control, as she had with her parents. This comment brought her back to earlier work, when Mrs. T had remembered her parents describing the "awful tantrums" she had when she was a toddler, and talking about how helpless they felt in the face of her feelings. Overwhelmed by anxiety and rage from inside, the toddler had been met by equally overwhelmed grown-ups; she was thrown on her own resources to deal with her feelings, and developed omnipotent fantasies of control. The analyst noted how such fantasies might have seemed the only available avenue at the time and wondered what had made Mrs. T feel equally resourceless in the present. Mrs. T laughed and said, "It's the same old stuff - there are no guarantees and I really do wish I could have a warranty." The analyst wondered aloud what Mrs. T really could depend on after she finished her analysis.

This material opened a path to discussion of Mrs. T's ideas about what things would be like after termination. Throughout the treatment there was a struggle within Mrs. T between the wish to hold on to past patterns of sadomasochistic relationships that represented infantile solutions with the hope of magical gratification, and the progressive forces that represented realistic relations with others and the world, mediated by competent functioning and yielding genuine, predictable pleasure. Focus on the therapeutic alliance tasks at each phase of treatment allowed for the emergence and consolidation of an alternate system of self-esteem regulation, rooted in pleasure from competent functioning rather than sadomasochistic omnipotent control of others. Setting aside 
her infantile wishes from all levels of development, including magical omnipotent images of perfection in herself and others, seemed a frightening and painful loss. But the work of the earlier phases of treatment allowed for the establishment of alternative sources of security and selfesteem in realistic achievements and representations. Much of the work of the termination phase involved drawing the distinction between the illusory loss of unreal fantasy gains and the real loss of the setting, the analyst, and the special therapeutic relationship. This contrast was drawn first during the earlier exploration of Mrs. T's fantasy fear of the total disappearance of the therapist into space. The hostile wishes contained in these fears and the assumption of omnipotence of thought demanded continued and repeated work at each phase of treatment. At termination, however, these fears became particularly intense in the face of the reality of ending.

Mrs. T oscillated between comfort in staying with the reality of the imminent end and fantasies about ways she could get the analyst to change the date, their relationship, or himself. A week before the termination date, she seemed low-keyed and somewhat quieter than usual. "I'd like to write a different ending to this story," she remarked. The analyst recalled how much they had learned together from the characters in her stories and wondered how Mrs. T would understand a character who tried so hard to redesign the world. Mrs. T snapped back, "I don't need a character to know I can't stand disappointment!" Then she said, "I really surprised myself with that. I guess it was waiting there to come out, but I have been fighting it off. Maybe that's why I've been feeling so subdued." She went on to examine the idea of being disappointed and faced her feeling that the analyst had not been the perfect mother she had always wished for, nor was she herself ever going to be the perfect person she had for so long striven to be. "Maybe now, though, I won't have to run off to have affairs to let myself know that what I really feel is all right." The Greensonian view of the therapeutic alliance as rational, stable, autonomous, and based on a real relationship is approximated at the end of treatment, is a result of treatment, and can be thought of as a goal of treatment.

\section{Posttermination Phase}

Posttermination is not strictly speaking a phase of treatment, but much of the work of analysis is shaped by its goals and measured by the quality of life afterward. Analysis is not an end in itself but a means to 
reach the goal of restoration to the path of progressive development. We have described how a focus on the therapeutic alliance allows for a concentration of resistance and conflict within the treatment, with particular illumination of sadomasochistic aspects of pathology. The work of the termination phase has facilitated internalization of the alliance and consolidation of new levels of relating, feeling, and cognitive functioning, to be used after treatment for living and independent analysis when necessary. Implicitly, the entire analysis has been a preparation for posttreatment living.

The analyst's posttermination alliance task is to maintain his stance as the patient's therapist, despite any internal or external pressures to alter the relationship. Continuing positive growth after treatment is possible only when there is some continuity between the period of the analysis and afterward. Many patients have had the fantasy image of analysis as something terribly painful to be endured in return for some subsequent prize, such as perfect happiness, no further conflict, and an ongoing, altered relationship with the analyst as friend, lifelong advisor, or lover. Analysts too have fantasies of an altered posttreatment relationship with their patients, and these have to be worked through if the termination is to be truly constructive (Viorst 1982; J. Novick 1997). Mrs. T had worked hard on a temptation to keep her analysis as a secret affair, an experience of acknowledging her own wishes and desires that she could not share with anyone other than the analyst. During the termination phase she had increasingly opened her heart to her husband, and he had been able to respond with greater involvement and understanding. A year after termination, Mrs. T wrote to the analyst, saying that everything was going well. She had, however, dreamed that she had an unpaid bill and wondered whether that indicated some unfinished business from her treatment. The analyst replied with thanks for her news, and said that he thought there would always be unfinished business for everyone, but that her question implied that she was setting to work on it. He noted that she could always contact him if she became stalled in her endeavors and wished her well.

After another year had passed, Mrs. T sent the analyst a copy of a recently published story, with a note to say that she had wanted to share her good feelings at this accomplishment. The story was in the form of an old woman's reminiscence about keeping secrets throughout her life. The bittersweet treatment of this theme represented a further reworking of Mrs. T's lifelong conflicts, transformed 
and integrated in a creative product that gave her new perspectives and expressive channels.

\section{CONCLUDING REMARKS}

Our revised theory of the therapeutic alliance is not meant to replace classical formulations, but rather to add to and enhance understanding and practice. The therapeutic alliance is a lens that helps us focus on the capacities and motivations, conscious and unconscious, from all levels of the personality and all stages of development, that enter into the specific collaborative tasks of each phase of treatment. The therapeutic alliance task specific to any particular phase confronts different strands from the development of omnipotent fantasy. Mrs. T's omnipotent delusion of perfection was illuminated by the evaluation phase tasks of transformation. Her need to externalize aspects of her own personality and thereby create a sadomasochistic bond with the analyst was revealed by the beginning phase task of being together. Mrs. T's resistance to the pleasure of collaborative work and creativity appeared through the filter of the middle phase task of working together. Her continuing need to control the object made it difficult for her to accomplish the pretermination phase task of taking responsibility for herself and her treatment. Finally, the omnipotent denial of time, change, sadness, and mortality became vivid through the lens of the termination phase alliance tasks of mourning and internalization. Grappling with the tasks of the therapeutic alliance at each phase of treatment restored to Mrs. T her potential for adaptive transformation. From accomplishing the alliance task of being with another came confidence in her capacity to be alone with herself, to value herself, and to cooperate in a trusting, mutually enhancing relationship with others. She could use a new level and range of ego functions activated in working together with the analyst for creative, joyful living and for self-analysis when necessary. The skill of self-analysis was developed in the context of a focus on independent therapeutic work. Setting aside magical infantile fantasy solutions strengthened Mrs. T's competent, reality-attuned mode of self-regulation. The capacities restored and the tools forged in the accomplishment of these therapeutic alliance tasks equipped Mrs. T for her lifelong struggle against the potential to resolve conflicts with sadomasochistic, omnipotent fantasies. The old woman in Mrs. T's last story tells her granddaughter that "secrets are fun to make up, but feel even better shared." 


\section{REFERENCES}

AleXANDER, F. (1950). Analysis of the therapeutic factors in psychoanalytic treatment. Psychoanalytic Quarterly 19:482-500.

(1956). Psychoanalysis and Psychotherapy: Developments in Theory, Technique and Training. New York: Norton.

\& French, T.M. (1946). Psychoanalytic Therapy: Principles and Application. New York: Ronald Press.

BalinT, M. (1968). The Basic Fault. London: Tavistock.

BIBRING, E. (1937). Symposium on the theory of the therapeutic results of psycho-analysis. International Journal of Psycho-Analysis 18:170-189.

BıON, W.R. (1977). Seven Servants: Four Works by Wilfred R. Bion. New York: Aronson.

BLUM, H.P. (198I). Some current and recurrent problems of psychoanalytic technique. Journal of the American Psychoanalytic Association 29:47-68.

Bollas, C. (1987). The Shadow of the Object: Psychoanalysis of the Unthought Known. London: Free Association Press.

BRENNER, C. (1979). Working alliance, therapeutic alliance, and transference. Journal of the American Psychoanalytic Association 27:137-157.

Breuer, J., \& Freud, S. (1893-1895). Studies on hysteria. Standard Edition 2.

CURTIS, H. (1979). The concept of the therapeutic alliance: Implications for the "widening scope." Journal of the American Psychoanalytic Association 27:159-192.

EISSLER, K.R. (1953). The effect of the structure of the ego on psychoanalytic technique. Journal of the American Psychoanalytic Association 1:104-143.

ERIKSON, E. (1950). Childhood and Society. New York: Norton.

EtChegoyen, R.H. (I99I). The Fundamentals of Psychoanalytic Technique. London: Karnac Books.

Farber, S., \& Green, M. (1993). Hollywood on the Couch. New York: William Morrow.

Fenichel, O. (194I). Problems of Psychoanalytic Technique. New York: Psychoanalytic Quarterly.

FERENCZI, S. (1928). The elasticity of psychoanalytic technique. In Final Contributions to the Problems and Methods of Psycho-Analysis. London: Hogarth Press, pp. 87-101.

FINE, R. (1979). A History of Psychoanalysis. New York: Columbia University Press.

FrankL, L., \& HELLMAN, I. (1962). The ego's participation in the therapeutic alliance. International Journal of Psycho-Analysis 43:333-337.

Freud, A. (1950). The problem of training analysis. In The Writings of Anna Freud, vol. 4. New York: International Universities Press, 1973, pp. 407-421. 
(1954). The widening scope of indications for psychoanalysis: Discussion. In The Writings of Anna Freud, vol. 4. New York: International Universities Press, 1973, pp. 356-379.

(1962). Assessment of childhood disturbances. Psychoanalytic Study of the Child 17:149-158.

_ (1965). Normality and Pathology in Childhood. New York: International Universities Press.

(1966). A short history of child analysis. In The Writings of Anna Freud, vol. 7. New York: International Universities Press, 1976, pp. 48-58.

FreUd, S. (1900). The interpretation of dreams. Standard Edition 4/5.

(1905). Three essays on the theory of sexuality. Standard Edition 7:123-243.

- (1909). Letter to Jung. In The Freud-Jung Letters, transl. R. Manheim \& R.F.C. Hull. Princeton, NJ: Princeton University Press. (I9/2). The dynamics of transference. Standard Edition 12:97-108. (19I3). On beginning the treatment. Standard Edition 12:123-144. (1928). Letter to Ferenzci. In I. Grubrich-Simitis, Six letters of Sigmund Freud and Sandor Ferenzci on the interrelationship of psychoanalytic theory and technique. International Review of Psycho-Analysis 13:259-277, 1986.

- (1937). Analysis terminable and interminable. Standard Edition $22: 1-182$.

(1940). An outline of psycho-analysis. Standard Edition 23:139-207.

FriedMAN, L (1969). The therapeutic alliance. International Journal of Psycho-Analysis 50:139-153.

Frieswyk, S.H., Allen, J.G., Colson, D.B., Doyne, L., Gabbard, G.O., HorowITZ, L., \& NEWSON, G. (1986). Therapeutic alliance: Its place as a process and outcome variable in dynamic psychotherapy research. Journal of Consulting and Clinical Psychology 54:32-38.

GeLso, C.J., \& CARTER, J. (1985). The relationship in counseling psychotherapy. The Counseling Psychologist 13:155-244.

GILL, M. (199I). Indirect suggestion. In Interpretation and Interaction, ed. J.J. Oremland. Hillsdale, NJ:Analytic Press, pp. 137-163.

_- (1995). Classical and relational psychoanalysis. Psychoanalytic Psychology 12:89-107.

GITELSON, M. (1967). Analytic aphorisms. Psychoanalytic Quarterly $36: 250-170$.

GLOVER, E. (1955). The Technique of Psychoanalysis. New York: International Universities Press.

GreenberG, J. (1991). Oedipus and Beyond. Cambridge: Harvard University Press.

(1995). Psychoanalytic technique and interactive matrix. Psychoanalytic Quarterly 64:1-22. 
Greenson, R. (1965a). The problem of working through. In Drives, Affects, Behavior, vol. 2, ed. M. Schur. New York: International Universities Press, pp. 277-314.

(1965b). The working alliance and the transference neurosis. In Explorations in Psychoanalysis. New York: International Universities Press, 1978, pp. 199-224.

(1970). Discussion of "The nontransference relationship in the psychoanalytic situation." International Journal of Psycho-Analysis 51:143-150.

(197I). The "real" relationship between the patient and the psychoanalyst. In Explorations in Psychoanalysis. New York: International Universities Press, 1978, pp. 425-440.

\& WEXLER, M. (1969). The nontransference relationship in the psychoanalytic situation. In Explorations in Psychoanalysis. New York: International Universities Press, 1978, pp. 359-386.

Grotstein, J.S. (1990). Introduction. In M.I. Little, Psychotic Anxieties and Containment: A Personal Record of An Analysis with Winnicott. Northvale, NJ: Aronson, pp. 3-11.

HAMM, M. (1967). Some aspects of a difficult therapeutic (working) alliance. In The Child Analyst at Work, ed. E.R. Geleerd. New York: International Universities Press, pp. 185-205.

HANLY, C. (1994). Reflections on the place of the therapeutic alliance in psychoanalysis. International Journal of Psycho-Analysis 75:457-467.

HARLEY, M. (1967). Transference developments in a five-year-old child. In The Child Analyst at Work, ed. E.R. Geleerd. New York: International Universities Press, pp. 115-141.

Hartmann, H., Kris, E., \& Loewenstein, R.M. (1964). Papers on Psychoanalytic Psychology. Psychological Issues Monograph 14. New York: International Universities Press.

Heinssen, R.K., LeVENdUSKY, P.G., \& HUNTER, R.H. ( 1995). Client as colleague: Therapeutic contracting with the seriously mentally ill. American Psychologist 50:522-532.

Horvath, A.O., \& Greenberg, L.S. (1994). The Working Alliance: Theory, Research and Practice. New York: Wiley.

KANZER, M. (1979). Book essay: Developments in psychoanalytic technique. Journal of the American Psychoanalytic Association 27:327-374.

KARON, B.P. (1989). The state of the art of psychoanalysis: Science, hope, and kindness in psychoanalytic technique. Psychoanalysis and Psychotherapy 7:99-115.

KHAN, M.M.R. (1974). The Privacy of the Self. London: Hogarth Press.

KLEIN, M. (1946). Notes on some schizoid mechanisms. In Envy and Gratitude \& Other Works, 1946-1963. New York: Delacorte Press / Seymour Lawrence, 1975, pp. 1-24. 
КонUт, H. (197I). The Analysis of the Self. New York: International Universities Press.

(1977). The Restoration of the Self. New York: International Universities Press.

LANGS, R. (1975). Therapeutic misalliances. In Technique in Transition. New York: Aronson,1978, pp. 155-188.

LOEWALD, H.W. (1960). On the therapeutic action of psychoanalysis. International Journal of Psycho-Analysis 41:16-33.

MEISSNER, W.W. (1992). The concept of the therapeutic alliance. Journal of the American Psychoanalytic Association 40:1059-1087.

_ (1996). The Therapeutic Alliance. New Haven: Yale University Press.

MeYERS, H. (1988). A consideration of treatment techniques in relation to the functions of masochism. In Masochism: Current Psychoanalytic Perspectives, ed. R. Glick \& D.I. Meyers. Hillsdale, NJ: Analytic Press, pp. 175-189.

Moore, B.E., \& Fine, B.D. (1990). Psychoanalytic Terms and Concepts. New Haven: Yale University Press.

Novick, J. (1970). The vicissitudes of the working alliance in the analysis of a latency girl. Psychoanalytic Study of the Child 25:231-256.

(1976). Termination of treatment in adolescence. Psychoanalytic Study of the Child 31:389-414.

(1980). Negative therapeutic motivation and negative therapeutic alliance. Psychoanalytic Study of the Child 35:299-320.

(1982a). Termination: Themes and issues. Psychoanalytic Inquiry 2:239-365.

(1982b). Varieties of transference in the analysis of an adolescent. International Journal of Psycho-Analysis 63:139-148.

(1988). Timing of termination. International Review of PsychoAnalysis 69:307-318.

(1990). The significance of adolescent analysis for work with adults. In The Significance of Child and Adolescent Analysis for Work with Adults, ed. S. Dowling. Madison, CT: International Universities Press, pp. 81-94.

(I99I). The therapeutic alliance: A concept revisited. Paper presented to the American Psychological Association, San Francisco, August.

(1992). The therapeutic alliance: A concept revisited. Child Analysis 3:90-100.

(1997). Termination conceivable and inconceivable.Psychoanalytic Psychology 14:146-162.

(1999). Deferred action and recovered memory: The organization of memory in the reality of adolescence. Child Analysis 4, in press.

\& NovicK, K.K. (199I). Some comments on masochism and the delu- 
sion of omnipotence from a developmental perspective. Journal of the American Psychoanalytic Association 39:307-328.

(1992). Deciding on termination: The relevance of child and adolescent analytic experience to work with adults. In Saying Goodbye, ed. A. Schmuckler. Hillsdale, NJ: Analytic Press, pp. 285-304.

(1994). Externalization as a pathological form of relating: The dynamic underpinnings of abuse. In Victims of Abuse: The Impact of Child and Adult Trauma, ed. A. Sugarman. Madison, CT: International Universities Press, pp. 45-68.

(1996a). A developmental perspective on omnipotence. Journal of Clinical Psychoanalysis 5:129-173.

(1996b). Fearful Symmetry: The Development and Treatment of Sadomasochism. Northvale, NJ: Aronson.

Novick, K.K. (199I). The therapeutic alliance in work with parents. Paper presented to the American Psychological Association, San Francisco, August.

\& Novick, J. (1987). The essence of masochism. Psychoanalytic Study of the Child 42:353-384.

(1994a). Postoedipal transformations: latency, adolescence, and pathogenesis. Journal of the American Psychoanalytic Association 42:143-170.

(1994b). Sadomasochism and the therapeutic alliance: Implications for clinical technique. New York Freudian Society, Washington, DC, October.

(1996). An application of the concept of the therapeutic alliance to sadomasochistic pathology. Paper presented to the Michigan Psychoanalytic Society, February, and the American Psychoanalytic Association, December.

Nunberg, H. (1928). Problems of therapy. In Practice and Theory of Psychoanalysis, vol. 1. New York: International Universities Press, 1948, pp. 105-119.

- (1932). Principles of Psychoanalysis. New York: International Universities Press, 1955.

PigmaN, G.W. (1995). Freud and the history of empathy. International Journal of Psycho-Analysis 76:237-256.

RAPAPORT, D. (1960). On the psychoanalytic theory of motivation. In Nebraska Symposium on Motivation, ed. M.R. Jones, pp. 173-247.

RAWN, M.L. (199I). The working alliance: Current concepts and controversies. Psychoanalytic Review 78:379-389.

RENIK, O. (1993). Analytic interaction: Conceptualizing technique in light of the analyst's irreducible subjectivity. Psychoanalytic Quarterly 62:553-571. (1995). The role of an analyst's expectations in clinical technique: Reflection on the concept of resistance. Journal of the American Psycho- 
analytic Association 43:83-94.

SANDLER, A.-M., \& SANDLER, J. (1994). Therapeutic and countertherapeutic factors in psychoanalytic technique. Psychoanalysis in Europe: Bulletin 43:45-56.

Sandler, J., Dare, C., \& Holder, A. (1973). The Patient and the Analyst. London: Allen and Unwin.

Kennedy, H., \& TYSON, R.L. (1980). The Technique of Child Psychoanalysis: Discussions with Anna Freud. Cambridge: Harvard University Press.

SCHLESSINGER, N., \& RobBINS, F.P. (1983). A Developmental View of the Psychoanalytic Process: Follow-up Studies and Their Consequences. New York: International Universities Press.

SHAUGHNESSY, P. (1995). Empathy and the working alliance: The mistranslation of Freud's Einfühlung. Psychoanalytic Psychology 12:221-231.

SHENGOLD, L. (1995). Delusions of Everyday Life. New Haven: Yale University Press.

SPENCE, D. (1982). Narrative Truth and Historical Truth. New York: Norton.

SterBA, R. (1934). The fate of the ego in analytic therapy. International Journal of Psycho-Analysis 15:117-126.

846 STONE, L. (1954). The widening scope of indications for psychoanalysis. Journal of the American Psychoanalytic Association 2:567-594.

(196I). The Psychoanalytic Situation: An Examination of Its Development and Essential Nature. New York: International Universities Press.

TAHKKA, V. (1993). Mind and Its Treatment: A Psychoanalytic Approach. Madison, CT: International Universities Press.

VIORST, J. (1982). Experiences of loss at the end of analysis: The analyst's response to termination. Psychoanalytic Inquiry 2:399-418.

WEINSHEL, E.M. (1984). Some observations on the psychoanalytic process. Psychoanalytic Quarterly 53:63-92.

WINNICOTT, D.W. (1965). The theory of the parent-infant relationship. In The Maturational Processes and the Facilitating Environment. New York: International Universities Press, pp. 37-55.

ZetZeL, E.R. (1956). Current concepts of transference. International Journal of Psycho-Analysis 37:369-376.

(1965). The theory of therapy in relation to a developmental model of the psychic apparatus. International Journal of Psycho-Analysis 46:39-52.

617 Stratford Drive

Ann Arbor, MI 48104

Fax: 734-665-2875

E-mail:Jnovick@umich.edu 